Muséologies

Les cahiers d'études supérieures

muséologies

\title{
Exploring Community Outreach Initiatives for Artist-Run Centres: A Case Study Using Anti-Racist Feminist Pedagogies to Create Inclusive Spaces for Knowledge Exchange
}

\section{Skye Maule-O'Brien}

Volume 7, numéro 1, 2014

Le dialogue dans les musées d'art contemporain

URI : https://id.erudit.org/iderudit/1026651ar

DOI : https://doi.org/10.7202/1026651ar

Aller au sommaire du numéro

Éditeur(s)

Association Québécoise de Promotion des Recherches Étudiantes en

Muséologie (AQPREM)

ISSN

1718-5181 (imprimé)

1929-7815 (numérique)

Découvrir la revue

Citer cet article

Maule-O'Brien, S. (2014). Exploring Community Outreach Initiatives for Artist-Run Centres: A Case Study Using Anti-Racist Feminist Pedagogies to Create Inclusive Spaces for Knowledge Exchange. Muséologies, 7(1), 141-156. https://doi.org/10.7202/1026651ar

Tous droits réservés (C) Association Québécoise de Promotion des Recherches Étudiantes en Muséologie (AQPREM), 2014
Ce document est protégé par la loi sur le droit d'auteur. L'utilisation des services d'Érudit (y compris la reproduction) est assujettie à sa politique d'utilisation que vous pouvez consulter en ligne.

https://apropos.erudit.org/fr/usagers/politique-dutilisation/ 
Article six

\section{Exploring Community Outreach}

Initiatives for Artist-Run Centres:

A Case Study Using Anti-Racist

Feminist Pedagogies to Create Inclusive Spaces for Knowledge Exchange

Skye Maule-O'Brien 
Skye Maule-O'Brien's interests lie in raising social consciousness and transformative learning through creative and critical pedagogy. She holds a BFA in Art History with a minor in Adult Education and a Master's Degree in Educational Studies from Concordia University. Currently living in Toronto pursuing a $\mathbf{P h D}$ in Education at York University, her research is rooted in anti-racist feminism with a focus on community knowledge and how race intersects with sexuality and gender to inform our lives. skyemo@gmail.com 


\section{Introduction: A Contemporary Issue}

In the fall of 2005, during a public discussion at the Musée d'art contemporain de Montréal (MACM), a heated debate arose around the subject of cultural diversity inside art institutions. Responding to audience members, Marc Mayer, the Director of the MACM at the time (2004-2008), admitted that though the museum was starting to think about issues of inclusion in programming, it had not been a prevalent matter thus far in Montreal, and the museum was "not interested in making any qualitative compromises in the program in order to reflect the cultural diversity of the city" ${ }^{1}$. As the conversation deepened, attendees brought forth questions of invisible citizenship ${ }^{2}$; communities of people who call Montreal their home but whose voices are not included in the social or political fabric of the city. As audience members took to the microphone to demand for museum programming to better reflect the identity of Montreal, Mayer replied:

We want the real Montreal to feel it's represented by the museum and its program. [...but] we are not looking to represent the margins in the museum.

We are looking to represent excellence ${ }^{3}$.

This discussion at the MACM is demonstrative of a recurring dialogue that becomes trapped in simplistic readings of what diversity means in public art spaces. Art practices that live outside of traditional canonical ideologies are continually prescribed as marginal and read as compromises of so-called excellence. To break the perpetuation of such hierarchical dichotomies of center versus periphery, complex negotiations of plurality must be engaged.

1 Musée d'art contemporain de Montréal. Mise au jeu, volet 2 partie 2. < archive.org/details/MarcMayerandChrisHand_1> (retrieved in January, 2013).

2 Ibid.

3 Ibid.

4 DEI, George J. Sefa. "The challenges of anti-racist education in Canada”. Canadian Ethnic Studies. vol. 25, no.2, 1993, pp. 36-51.

5 Cisgendered is the term used to describe a person whose biological sex matches their gender identity.
The ongoing process of reconceptualizing spaces and programming is not an end goal, but instead a path to exciting and challenging innovations within our institutions. Ultimately, it is such possibilities within dialogue that led me to become actively engaged in researching the dynamics of race, privilege, and power in a non-traditional art institution in Montreal.

As a community researcher who is writing about issues of race, sex, gender, and other forms of oppression and privilege within cultural spaces, and who recognizes lived realities as a source of knowledge ${ }^{4}$, I think it is important to position myself. I am an Anglophone, white, cisgendered ${ }^{5}$ female whose family settled in Canada from Scotland just over fifty years ago, making me a first-generation Canadian. It is from this location that I strive to reflect on my own privilege within a global society. I understand that my whiteness and its advantageous societal affordings can be problematic when addressing subjects covered in these pages, and such contentions will be explored. While a large focus of my writing is on race and the critical analysis of white supremacy within creative spaces, I do not wish to diminish the complexity of interlocking systems of oppression at play.

Quebecois art institutions are not free from shifting challenges affecting people and communities living in this province. Current government policies are creating deep divides amongst the population, with Quebec's Charter of Values (bill 60) ${ }^{6}$ proposal last year being a stark and frightening example. Unfortunately, efforts to challenge such racist and exclusionary socio-political realisms often are relegated to one-off exhibitions that feature the work of artists typically "othered" in the

6 Bill 60, proposed in September 2013 by the Parti Québécois, if passed would have amended Quebec's Charter of Human Rights and Freedoms to establish religious neutrality. The call for the removal of religious symbols from publicly funded institutions was the most controversial; the bill would have restricted employees from wearing head coverings such as a hijab, turban, or kippah. Bill 60 was accused of perpetuating racist ideologies, such as Islamophobia, and privileging Catholic heritage. 
mainstream art world, leading these institutions to feel they can check off their yearly diversity quotas. If museums are not willing to participate in changing practices they risk being left out of important conversations that address the realities of their audiences-the very people who give purpose and a future to their institutions. As Susan Ashley elucidates, today's citizens are no longer looking at the nationalistic and paternalistic role of the museum in uncritical ways". "Where global economics and popular culture combine with an unprecedented influx of immigrants" need to challenge the practices of art institutions is necessary to "temper the authoritative agency and certainty; remove homogeneity and single points of view, reject exclusion, encourage complexity and pluralism, and ensure conversation..." ${ }^{9}$. In a city such as Montreal, where language, race, and class divide the landscape through both invisible barriers and visible geographical patterns, it is important to analyze the often unquestioned positions of privilege held both by individuals and institutions if there are to be far-reaching changes.

As a method for re-thinking our contemporary struggle to initiate more inclusive and engaged community practices, I was drawn to the artistrun centre (ARC) model. A unique grassroots structure, ARCs- though not free from funding constraints or grant obligations-are able to foster practices that make it easier to respond to the needs of their communities. These centres are grounded in member-driven initiatives, processes of self-reflection, and create room for dissent through a commitment to forge community-oriented partnerships. As such, artist-run structures are inherently open to dialogue around membership and community relationships.

I began volunteering with one such ARC, articule, in 2007. I initially joined as a member to explore outreach, fundraising, and programming. I was impressed by their unusually

7 ASHLEY, Susan. "State authority and the public sphere: Ideas on the changing role of the museum as a canadian social institution”. Museum and Society. vol. 3, no. 1, 2005, pp. 5-17. $8 \quad I d .$, p. 5.

9 Id., p. 15 inclusive practice of holding four general assemblies per year to voice overall membership concerns with ongoing gallery activities. With their board of directors comprised of active voted-on gallery members, the mandate defines this non-profit centre as open-access, committed to artistic excellence, and proclaims the space to be, "dedicated to the presentation of a broad range of contemporary practices" ${ }^{10}$. articule strives for "interdisciplinarity and social engagement", while supporting a wide range of artists "to test the limits of aesthetic gesture," and employs "ideals of experimentation and risk-taking" ${ }^{11}$. The centre further asserts that its "open structure encourages the direct participation of an active and diverse membership on both programming and organisational levels" ${ }^{12}$.

In 2009, articule decided to revisit their practices and policies to determine if the centre was respecting its socially- and critically-engaged mandate. As an active gallery member and researcher, I designed and implemented an action-research project that examined this. The idea was to assist articule in a reflective project, but also to explore what larger arts institutions could learn from community based artist-run centre practices. The following questions were examined and will be addressed in this paper: Are notions of access and privilege being addressed on a continuous basis at articule? What changes can artist-run centres implement to be more connected to the communities in which they are located? Additionally, what can museums and larger civic institutions learn from community-run art organizations? The findings of this study offer concrete, attainable and flexible suggestions to positively incorporate difference and dialogue in art institutions, which can further expand membership and community participation. Examples are illustrated through a synopsis of the case study data collected from the two-day Recognizing Privilege \& Oppression Workshop that I carried out with articule.

10 articule. Mandate. <www.articule.org/web/menu02/mandat_en.html> (retrieved in November, 2012).

11 Ibid.

12 Ibid. 


\section{articule: Artist-Run Centres as a Model}

articule is an artist-run centre and contemporary gallery space that is located in the MileEnd - a trendy, neighbourhood of Montreal, best known today for its artists and Orthodox Jewish community. Once a haven of affordable apartments and studios, the area attracted an influx of artists' and their activities beginning in the early part of the 2000s. With the effects of gentrification, today the Mile-End has become a vibrant hub of galleries, boutiques, cafés, and increasingly expensive studios. articule, being one such gallery, moved into the area in 2006 to locate itself street level with storefront window visibility.

Though the move created resurgence in membership activity, the centre still felt that large segments of Montreal's creative communities were not being engaged. Even though articule is a bilingual ARC, which welcomes a large number of newcomers to the city, and thus supports quite a varied membership body in terms of age, gender, sexuality, language, and artistic mediums, the fact still remained that the gallery was mainly comprised of Englishspeaking, white, educated artists. It was with this recognition that the decision was made to reflect on the gallery's practices and policies through the development and implementation of the Recognizing Privilege \& Oppression Workshop. Unanimously supported by the board of directors and staff, the workshop was used as a method to determine whether articule was meeting its mandate and was keeping in line with the changing realities of the cultural and political climate.

13 DEI, George J. Sefa. Anti-racism education: Theory and practice. Halifax: Fernwood Publishing, 1996, p. 25.

14 Pedagogy for the privileged is an educational model developed by Ann Curry-Stevens, borrowing from Paulo Freire's Pedagogy of the Oppressed, as a method of transformative learning to recognize one's participation in the oppression of others and the responsibilities that entails. Working as a ten step educational process, she lays out the details in her article, "New Forms of Transformative Education: Pedagogy for the Privileged". Journal of Transformative Education. vol. 5, no. 1, 2007, pp. 33-58

15 This term, coined by Megan Boler in her book, Feeling power: Emotions and education (full citation in footnote 17), utilizes opportunities to address difficult subject matter as a way to promote transformative learning by moving through

\section{Using Anti-Racist Feminist Pedagogy Within Art Institutions}

Utilizing an anti-racist feminist pedagogical theoretical framework, heavily informed by the work of George J. Sefa Dei, a renowned scholar of anti-colonial and anti-racist education, the workshop became "an action-oriented strategy for institutional, systemic change to address racism and the interlocking systems of social oppression"13. Employing a combined approach of a pedagogy for the privileged ${ }^{14}$ and a pedagogy of discomfort ${ }^{15}$ in the curriculum, the aim was to promote social responsibility through transformative learning on an individual and institutional scale by deconstructing a "passively racist aesthetic"16. One claim of the workshop is that education is in no way neutral and is intimately tied to specific cultural agendas ${ }^{17}$. Given this, education is always a political and ethical undertaking, as any curricula may trigger resistance or anger ${ }^{18}$. In order for empowerment to be realized, one must move past the defensive emotions that are often used to mask fear of change and loss of identity ${ }^{19}$. Such empowerment must "involve undoing negative social constructions, so that people come to see themselves as having the capacity and the right to act and influence decisions" ${ }^{20}$.

By grounding the workshop in the above theoretical discourse, we, as a group, could disrupt, dismantle, reconfigure, redistribute, and equalize power dynamics ${ }^{21}$ working inside of articule. This involved participants developing a critical consciousness through an understanding of their individual positions within a larger

emotional reactions. This relates closely to anti-racist feminist education due to the fact that many people are uncomfortable openly discussing racism, privilege, and power.

16 BANNERJI, Himani. Thinking through: Essays on feminism, Marxism and anti-racism. Toronto: Women's Press, 1995, p. 45.

17 BOLER, Megan. Feeling power: Emotions and education. New York: Routledge, 1999, p. 180.

18 Ibid.

19 Ibid

20 Id., p. 14

21 MATHEWS, Ann et al., "Learning, difference, embodiment: Personal and collective transformations". New Horizons in Education. vol. 56, no. 1, 2008, pp. 45-63. 
societal and institutional context ${ }^{22}$. Employing feminist anti-racist strategies in the workshop involved naming and unpacking whiteness, not as a skin colour, but as a space of flux that is lived and acted in $^{23}$. Identifying whiteness as a systemic force, and a transparent or invisible reality, offered us a space to discover where we can critically examine the construction of identity in order to "re-think whiteness as both a discourse of critique and possibility" 24 . Moving from an individual, personal analysis, the workshop then led to conceptualizing how to respectively invite and learn from community voices not only in the Mile End, but around Montreal and internationally.

It can be argued that this approach is particularly essential in art institutions, as art has the potential to ignite imaginative possibilities for positive change. Museums, galleries, and ARCs have their own roles and responsibilities within our communities; offering varied perspectives from our educational systems on knowledge creation and meaning-making is one such role ${ }^{25}$. Art production comes from within our imaginations and is a reflection of our experiences, environment, and everyday realities. Belting writes, "art is no longer a theme of its own. It transforms itself into a commentary or mirror of contemporary themes, such as minority issues, traumatic memories, or cultural conflicts" ${ }^{26}$. Both art and education have the capability of promoting critical awareness through encouraged questioning and reflection, which can offer opportunities of transformation in values, beliefs, and possibly even worldviews. Art can be employed as a powerful and positive tool in tackling difficult issues while promoting new ways of analysis, knowing, and learning. As Clover notes, the imagination is a potentially

22 ROWLANDS, Jo. Questioning empowerment: Working with women in Honduras. United Kingdom \& Ireland: Oxfam, 1997.

23 GIROUX, Henry. "White squall: Resistance and the pedagogy of Whiteness”. Cultural Studies. vol. 11, no. 3, 1997, pp. 376-389.

24 Id., p. 384.

25 NORMAN, Ron. "Cultivating imagination in adult education". Proceedings of the Adult Education Research Conference, 2000. <www.adulterc.org/Proceedings/2000/normanr-final.PDF> (retrieved August, 2011). revolutionary force, which challenges us to pursue more complex readings of ourselves and of society, and discover new possibilities for how our institutions can contribute to our communities $^{27}$.

As demonstrated with the MACM conversation at the beginning of this paper, ideas of excellence and power have a strong hold over our cultural economies. These notions have long histories and far reaching effects on how we view the importance of dissenting aesthetic views.

When interrogating intuitional practices, we cannot ignore the cultural climate that breeds a specific set of values. In order to promote change, a certain degree of discomfort needs to be generated within the institutionalized culture, by introducing new aesthetic leanings, counter-voices, and community ties between organizations that are not necessarily alike. Thankfully, many art institutions are open and receptive to critique, as was witnessed in articule's responsiveness to participate in the rigorous reassessment of their institutional policies.

\section{Workshop Implementation}

The objective of the research was to collectively empower articule to take action through institutional modifications to programming, policies, and procedures; to break down oppressive, exclusionary systems that obscure participation by maintaining social and racial divides. Respecting articule's vision, "to provoke dialogue, $[\ldots]$ to foster critical thinking[,] and to promote a diversity of practices and experiences in the artistic and social realms" 28 , the two-part Recognizing Privilege \& Oppression

26 BELTING, Hans. "Place of reflection or place of sensation?” In. NOEVER, Peter (Ed.). The Discursive Museum. Vienna: Hatje Cantz Publishers, 2001, p. 76.

27 CLOVER, Darlene E. "Culture and antiracisms in adult education: An exploration of the contributions of arts-based learning”. Adult Education Quarterly. vol. 57, no. 1, 2006, pp. 46-61.

28 articule. Mandate. <www.articule.org/web/menu02/ mandat_en.html $>$ (retrieved in November, 2012). 
Workshop experimented with the possibilities of opening accessible and inclusive art spaces for knowledge creation and exchange. The workshop provided timely opportunities to de/ $\mathrm{re} /$ construct the individual and institutional roles in policy-making traditions and provided a proposed set of actions to be incorporated into an upcoming five-year strategic plan.

There were ten potential participants: seven board members (including myself) and the three administrative and coordinating paid staff of the gallery. Of the ten there were seven women and three men. Nine present as white, and one as a person of colour. All were between the ages of the ages of 25 and $45^{29}$. All participants at the time of our workshop were active in the local art community, had a post-secondary education and/or professional training. Most were bilingual with a few speaking more than two languages. Three participants came to Montreal from outside of Canada. Of the ten possible participants, one resigned from the board and another was living out of town and could not attend the first session. Eight people participated in the first workshop session on March $13^{\text {th }}, 2010$, and nine in the second on April 18 $8^{\text {th }}, 2010$.

The first session, drawing on Curry-Stevens' initial six steps in her ten step Pedagogy for the Privileged model, began with questions to assess the participants' awareness of privilege and oppression, and comfort with being instrumental in institutional transformation. The steps are as follows: step 1: awareness of oppression, 2: oppression as structural and thus enduring and pervasive, 3 : locating oneself as oppressed, 4: locating oneself as privileged, 5: understanding the benefits that flow from privilege, 6: understanding oneself as implicated in the oppression of others and understanding oneself as an oppressor ${ }^{30}$. Opting for holistic icebreakers and discussion-based activities, the workshop brought forward

29 Statistical data of age, race, gender, language, education, occupation, and migration history were not collected as part of the workshop; instead this knowledge was obtained by working closely with the group of people over a number of years. important issues to think about, particularly related to how individuals can influence the institutions we interact with on a daily basis. Combining both private reflections with group discussions, the participants interacted with challenging and emotional material. The purpose was to push people to recognize their social positions and to see themselves as both the oppressed and the oppressor. Starting the four-hour workshop was an introduction reminding the group of the main objectives informing the sessions, an overview of the day's agenda, and a discussion of the workshop guidelines to provide and maintain a space of support and respect ${ }^{31}$.

Our first activity, "Triggers", was an exercise to think about language, topics, or behaviour that may be personal emotional triggers: such as causing anger, distress, sadness, fear, or guilt. These are emotional spaces someone may find difficult to move through, or may cause that person to "shut down", thus halting conversation. "Triggers" can be a difficult activity to start with as it forces people to jump into a personal reflection process right off the bat, but I felt that it was an appropriate step to bring focus inwards, as the first day was centered around the individual. People were not forced to share, but it did allow for a moment of thought on challenging emotions that could be difficult to work through in a group setting, while also promoting a level of collective awareness and respect.

Next, using a light icebreaker activity, participants were asked to "describe [themselves] in 3 words". Most of the words that people wrote down were connected to what they perceive their personality to be, such as: energetic, daydreamer, optimistic, impulsive, talkative, and reflective. The round table discussion that followed was facilitated by the question of why we had chosen our three words, and the challenge of only being allowed three.

30 CURRY-STEVENS, Ann. "New forms of transformative education: Pedagogy for the privileged". Journal of Transformative Education. vol. 5, no. 1, 2007, pp. 33-58. 31 Guidelines adapted from Challenging White Supremacy (CWS) workshop. <http://www.cwsworkshop.org> (retrieved in June, 2008) 
Each person had the opportunity to explain their words' importance in how they relate to their identity construction, and whether they believed this is how other people viewed them. It was through this dialogue that the notion of "othering" was introduced, asking the group if they defined themselves against what they perceive themselves not to be in comparison to others. This description activity flowed nicely into the "Flower of Power" activity. Here participants used two differently coloured markers to shade in petals of a flower that was divided into descriptive identity binaries, such as gender, sex, race, religion, education, ability, and so on. This binary exercise furthered the discussion around "othering", as well as the strict and unrealistic uses of categories in society. A pertinent example was the gender binary of male and female. Due to the fact a number of people within our communities are gender nonconforming, this was an important point in the conversation and one that articule was addressing at the time. The discussion allowed for an analysis of how power, oppression, and privilege are fluid interlocking systems that inform each other depending on the individual and their interactions with institutions and systems. Some specific questions we looked at were: has this activity affected how you view yourself, your life, and/or how you engage with other people? How do your positions in society inform your position within articule? Participants also took the time to share their own experiences of oppression and how they felt about such experiences, which led to recognizing affinities that may or may not exist between forms of oppression. The tone of the workshop by this point turned quite serious. Personal exchanges during the "Flower of Power" activity formed some tension over disagreements regarding perceived experiences of oppression and victimhood, but this in some ways forced a deepening of the conversation asking for further engagement. No one stopped

32 It is important to note some participants were critical of Wise's lecturing style, accusing it of being rooted in a white colonial history of patriarchal aggression, utilizing an American religious preaching approach. participating, and people still seemed very comfortable sharing their personal and political opinions in relation to the petals.

The last activity of the day was to read over a portion of Peggy McIntosh's White Privilege: Unpacking the Invisible Knapsack Checklist. Looking at the first fifteen points on her list and discussing their relevance to our lives, I asked people to share their feelings and thoughts. As expected, McIntosh caused visible and vocal reactions within the group, as shifting from seeing oneself as oppressed to being an oppressor poses emotional and worldview-related challenges. In the closing of the first session we discussed how emotional reactions during such activities is normal and are an important step in working through difficult material.

There was a month between the first and second sessions of the workshop allowing for reflection and the writing down of any feelings or thoughts that we could address as a group at the next workshop. During this time, participants were also asked to finish reading McIntosh's list and to view a Tim Wise lecture called, "The Pathology of Privilege: Racism, White Denial \& the Costs of Inequality"32. The second workshop began by recapping McIntosh's points through a comparison with Wise. In his address, Wise stresses how seeing oneself as a possible agent of oppression can actually reveal false benefits of privilege, and that people unconsciously may participate in the oppression of others and ourselves because it has been framed as a norm by our society. For the most part Wise's lecture was well-received, and people thought his talk reiterated some of the issues we had talked about as a group previously ${ }^{33}$.

After a brief recapitulation of the first session, we moved away from individual reflective activities toward an institutional critique in the form of a guided brainstorming discussion to set objectives for articule. The purpose was

33 WISE, Tim. "The pathology of privilege: Racism, white denial \& the costs of inequality” (speech). Video Media Education Foundation. Mt. Holyoke College, October 1, 2007. 
not only to make tangible decisions for action, but also to examine our individual power as agents of change. As one of our board members had said at a previous meeting, although this undertaking may be tiring at times, it was nevertheless exciting to think of articule as a leader in the community. The core research questions that I had come to articule with firmly grounded our second session, as we set out to answer: what changes can artist-run centres implement to be more inclusive to the communities in which they are located? Are notions of access and privilege being addressed? And in what way should curatorial, programming, and display practices be challenged and/or modified?

Continuing with the pedagogical guiding tools I incorporated the 4 final steps of CurryStevens' ten-step, Pedagogy for the Privileged process: step 7: building confidence to take action-knowing how to intervene, step 8: planning actions for departure, step 9: finding supportive connections to sustain commitments, and step 10: declaring intentions for future action. Combined with these steps, I adapted the People's Institute for Survival and Beyond's (PISAB) set of "Anti-Racist Principles for Effective Organizing \& Social Transformation”, as key discussion points for the day in order to prioritize issues and keep the group concentrated on a solid plan of action. These organizing principles included: learning from history, sharing culture, developing leadership, maintaining accountability, networking, analyzing power, and gatekeeping ${ }^{34}$.

The Recognizing Privilege \& Oppression Workshop's second session's brainstorming discussion resulted in a number of categorized goals that were to be connected and implemented over the next five years as part of the strategic plan. The following raw data collected during the workshop, categorized under the PISAB's principles, showcases the guiding themes that led to lively dialogues that pushed participants to deconstruct power and privilege

34 The People's Institute for Survival and Beyond (PISAB). Our Principles. <www.pisab.org/our-principles $>$ (retrieved December, 2009). related to art institutions. Written in a collective voice ("we"), specifically highlighted are articule's plans in creating unique outreach initiatives and building collaborative community bridges, some of which were voted on by the board the same day. The text of that plan is as follows:

Analyze institutional power by rethinking structures as creative starting points. How can we be more accessible (physically and ideologically)? We can assume more of our institutional power, as we have the ability to define programming, community involvement, and actions. As a right to exercise our institutional power, we must remain open and seek out various funding options available to us from the three levels of government ${ }^{35}$ and more. Although we must be aware of institutional restraints and policies, inefficiency can sometimes create openness. As well, alignment with academia and/ or universities can be beneficial to utilize institutional intellectualism as a method of dialogue, critique, and change.

\section{Learn from (our 30+ year) history, but} also look forward. Learn to accept failure, and learn from mistakes and past outcomes. We recognize the need to support institutional memory, and put practices in place to pass on information from year to year, between past and new members.

Develop leadership in the ARC community, but learn to be more open through both internal and external critical reflection and evaluation. In the continuing effort towards better practice, develop a survey or suggestion box to hear public perception and feedback more effectively. We will initiate collaborative efforts by making communities aware of articule's commitment to exchange and knowledge sharing.

35 National, provincial, and civic governments have funding programs available to ARCs. 
Network and outreach through better advertising initiatives to the general public and not just to the artist community. This could be through utilizing media—such as newspapers, magazines, radio, web presence, and publications - to promote activities, encourage public participation and awareness, while sharing resources. As a way to promote communication amongst members, we will encourage deeper engagement through supported open-studios, invited interdisciplinary speakers and show-and-tell events. We will prioritize and devote energy to the reception of collaborations and educational programming that are socially engaged, with the goal of implementing at least one larger-scale collaborative project per year.

Maintain accountability through clearly defining board objectives, respecting the mandate, and creating an advisory board and/or inviting non-voting community members to sit on the board. We will Oppression Workshop] activity's findings with the development of the strategic plan. Additionally, in relation to developing leadership above, we will generate an evaluation process through a system of surveying both external and internal relationships.

The Gatekeeper is an "agent of institutional transformation" ${ }^{36}$. Gatekeeping can be viewed as another form of maintaining accountability to encourage networking with those who share similar values ${ }^{37}$. Gatekeeping will be an ongoing responsibility of the board as a whole, and different members and staff will carry on the supportive and critical task ${ }^{38}$.

The final session of the workshop ended on a high and productive note with various ideas and actions having concrete plans attached to how they would come to fruition. It had been previously decided to incorporate a board meeting at the end of the workshop as a way to vote on some of the discussed action plans. This also ensured the commitment to connect the work that was done over the two sessions of the Recognizing Privilege \& Oppression Workshop with the upcoming five-year strategic plan the board was about to embark on. It was during this board meeting that we voted unanimously to engage in at least one collaborative project per year, starting with the next programming cycle. The focus to promote creative collaboration was not contingent on its relevance or relationship to art production. Instead, the initiatives would be responsive to the communities being engaged as a method to share resources and power.

\section{Workshop Outcomes and Future Goals}

Promising results were realized after the workshop and the subsequent production of the strategic plan. The institutional shifts and programming changes occurring inside articule caused excitement within the membership, sparking creative ideas of reallocating funds and redistributing efforts into community development and outreach. These initiatives included articule's outreach committee conducting a survey with visitors, membership, and the online community to assess desires and needs. articule also began hosting joint artist talks to provide a more dialogical approach, inviting counter-voices and expertise to themed topics, which resulted in record breaking attendance. Further, answering a loud call for action from the community, the gallery's front door entrance was modified by removing the stairs and installing a ramp to make the space accessible. This allowed the centre to be made available to collectives that do not have permanent locations, and expand community partnerships by meeting the

38 It was decided by the group that I would take on the role of gatekeeper for the 2010/2011 year, after which another staff or board member would assume the role.
36 The People's Institute for Survival and Beyond (PISAB). Our Principles. <www.pisab.org/our-principles $>$ (retrieved December, 2009). 37 Ibid. 
requirements of a growing number of organizations to only collaborate or host events in wheelchair accessible locations.

In order to support these ambitious projects, articule's board and human resources committee made changes to job descriptions to modify staff workloads by allocating tasks differently, and created a new position solely focused on outreach. By hiring a new outreach coordinator who had extensive experience working with diverse artistic communities as well as anti-oppressive practices, articule witnessed even greater numbers of collaborative projects during the two subsequent programming years, far exceeding the minimum goal of one per year. To mention only three ${ }^{39}$, these partnerships included; Diasporasie: a weekend long art symposium collaboratively organized between articule, SAVAC (South Asian Visual Arts Centre, Toronto), La Centrale (Montreal), and MAI (Montréal, arts interculturels); The Mile End Art Map: a multi-part project of workshops, discussions, walks, and an exhibition in which articule invited fellow Mile End residents, "galleries, artist-run centres, and other places of cultural and artistic interest", to take part in collective creative cartography ${ }^{40}$; and The Living Histories Theatre Ensemble (LHTE): a "playback theatre performance focusing on the experiences of lesbian, gay, bisexual, transgendered/transsexual, and queer (LGBTQ) refugees and new immigrants" ${ }^{41}$, a collaboration with Agir, and Au-délà Arcen-ciel. All three programming undertakings brought together diverse and intersecting experiences with the goal of producing new forms of knowledge that could act as counter-narratives to challenge what it means to create art defined by excellence.

39 For more details on the discussed programming, special projects, and collaborative events please see the articule archives: <http://www.articule.org/web/archive/10-11_en.html> and $<$ http://www.articule.org/web/menu01/expositions_en.html>

\section{Applications for Other Art Institutions}

Though articule clearly demonstrated productive outcomes throughout the reflective action process, embarking on a journey of transformation always brings challenges. articule's challenges are mainly centralized around high membership turnover and time and workload constraints. articule will have to keep readdressing such issues to ensure the efforts made during and after the workshop series and strategic planning are passed on, respecting institutional memory. Many other ARCs and art organizations may share similar concerns, although their outcomes may differ. Making the learning and knowledge personalized is a key aspect of such a process, but learning from what others have experienced is also important. As a knowledge-sharing method, much of the results of the workshop at articule are very applicable to a variety of arts institutions. The original goal of the workshop was to develop a curriculum that was flexible enough to be modified depending on the needs of the group or institution utilizing it. Ultimately museums and larger galleries have different roles in civic landscapes than those of ARCs, and thus will have varying reasons for why they would participate in similar workshops or movements to create institutional changes. The following three sections outline a number of suggestions for art institutions, which evolved from my extensive work with articule over a four-year period, personal learning obtained through both an academic setting and community dialogue around diversity issues affecting art organizations, as well as an incorporated analysis of the Recognizing Privilege \& Oppression Workshop results.

\section{Learning exchanges}

In this research, articule's strong drive to engage in reflective practices and actively implement strategies for positive change are reasons to be optimistic about the potential

40 articule. The 2012 Mile end art map. <http://www. articule.org/web/expositions/11-12/mile_end_map_en.html> (retrieved in April, 2013).

41 articule. Living Histories Theatre Ensemble playback theatre. <http://www.articule.org/web/evenements/10-11/playback_en.html > (retrieved in April, 2013). 
for art institutions to become more critical, action-oriented locations. Taking the historical and current social, political, and cultural landscape into account, it may just take time for this awareness and passion to grow within art institutions. An obstacle to change can be seen in the lack of learning opportunities pertaining to critical reflective practices in arts institutions. Insufficient awareness of how to approach the issues that arise out of these reflective processes only exacerbates the problem. Asking artists, educators, and even entire organizations to work together can help resolve such issues in order foster meaningful learning exchanges. Workshops, discussions, lectures, and tours, as interactions should work to address the needs of individuals, as people bring a lifetime of experiences to the table. Listening to the people who make up, and who are affected by the institutions is of utmost importance to actualize positive institutional change. As Boler asks, "what helps us to develop, collectively, the courage to see things differently?" ${ }^{2}$ Disagreements and differences personal politics will present some of the biggest challenges. These include emotional triggers and insecurities along with valuable skills and wisdom. This is precisely why addressing individuals as part of the process-as what was done in articule's Recognizing Privilege \& Oppression Workshop-is so integral to true institutional transformation.

\section{Reassessing aesthetic values}

Aesthetic values and social topic trends that define what "good" art is can work to exclude not only artists but also the centres that are introducing alternative aesthetic leanings. Institutions can move within and through communities in a similar way that people do. Different groups of people and associations can utilize different spaces. A gallery whose goal is to work in a more isolated community or one that would prefer to only pair with likeminded organizations would have different outcomes than a space such as articule. An art organization with a mandate committed to education and outreach, as well as responding

to the needs of artist and non-artist communities will need to adopt flexible programming and risk-taking strategies.

The area of programming is where some of the largest shifts must occur if a centre wants to become a more inclusive space. As it stands right now, most ARCs either invite artists to show their work, which is an extremely exclusive practice, or people are asked to submit proposals. Proposal writing can be a difficult competitive process that not only challenges artistic ideas and expression, but also literacy, language, and writing skills; artists must be good at selling themselves verbally. This can result in the exclusion of artists whose first language is neither English nor French, or who do not have the learned privileged cultural capital to compete with university-educated artists in this particular format. The difficulty can be further exacerbated through time constraints or commitments like families to care for or demanding jobs.

The definition of programming needs to have several facets for inclusivity. If a space only has long-term programming, for example, they are preventing themselves from responding to shorter-termed imaginative developments. Although making room for programming to acquire new forms may have its headaches, the process could bring new energy to an organization in the long run. Programming that moves between short- and long-term, inside and outside the gallery, through different mediums, can reach a wider public, giving those who may be unfamiliar with ARC structures an opportunity to get acquainted through alternative practices.

Also related to programming is the acquisition of proposals, and the ways in which calls for proposal are circulated. Spreading the word outside of ARC communities and beyond regular communication avenues takes research and effort, but can assist in broadening audiences and artists. Additionally, ARCs, including articule, have the ability to expand their proposal submission guidelines drastically. Instead of 
asking for a list of strict specifics, submissions themselves could take on added creativity, thus increasing the pool of applicants. Selecting proposals or programming through conversations or interviews, holding events or large brainstorming sessions, and pairing with community groups are all possible strategies.

As arts institutions ideally aim to serve the communities in which they are located, it is their obligation to address oppressive traditions and policies with much greater rigor and radical innovations than have been witnessed thus far. It is recommended that art organizations include and support artists whose statements are defined by making art for non-commercial purposes. This could consist of public art, relational aesthetics, installations, street art, performance, body art, and much more. Furthermore, art being created outside of privileged circles cannot be excluded based on whether or not its location of production is associated with a dominant tradition.

In short, there is a need to foster spontaneous programming and curatorial strategies to become more inclusive as an organization. Letting go of the comfort and control that long-term programming offers has its risks, but when discussing accessibility, compromise is a must.

\section{Developing artistic connections}

There can be an enormous disconnect between the practices of large arts institutions and the realities of the city they are located in. As Illeris states:

[...] empowerment is not only about taking personal responsibility for one's own learning processes but also about improving the general quality of life in the community. In the case of the museum and gallery education this means that we must consider education as not just an individual benefit, but as a social activity embedded in the surrounding social settings ${ }^{43}$.

Institutions operating without a socially-engaged lens are exposed to criticism that their guiding curatorial decisions are maintaining the canon by choosing comfortable and familiar subjects of diversity as a way to stay clear of politicized conversations. It is understandable that those discussions come at a risk and will undoubtedly be uncomfortable, but now, more regularly, the choice to participate in tokenizing artists as a tactic to avoid public scrutiny is being shamefully called out. And so it should be. The Band-Aid approach to issues of inclusion-showing one-offs of controlled, safe topics-does not effectively promote examinations of difference, power, and privilege nor does it encourage institutions and their publics to share and investigate complicated, multifaceted artistic practices and experiences.

It will always be the case that some institutions will be more open to change and explorative methods to engage with than others. Already, some are attempting to include leaders and members of non-dominant cultural communities to assist in these shifts. This has been through opening a dialogue and working towards alternative exhibitions and display practices, such as is done with articule's special projects - a short-term, ongoing programming stream with the specific goal to transgress the boundaries of the gallery to engage with communities. Or through a deepening of educational programming within museum walls, which has been witnessed through articule opening up the gallery space to be used by various organizations who may not have a permanent location or who need larger spaces to host events or workshops. Both ARCs and larger galleries and museums could benefit from forming links between grassroots communities, organizations, and institutions to take efforts even further. 


\section{Conclusion and Future Challenges}

The benefit of the presented action-based research was that it sparked a dialogue focused on salient societal problems affecting artistic visioning and programming for ARCs, galleries, and museums. As one workshop participant pointed out, for them, the workshop brought up a great deal of concerns as to where articule positioned itself in the context of Quebec's political strife. I share these concerns along with the hope that they may be addressed in future conversations and research; specifically with regards to settler colonial realities and the "diverse range of Aboriginal Peoples and First Nations, who have historically been and continue to be oppressed by both Quebec and Canadian society" ${ }^{44}$. There is a great need for closer analysis of how the shared theoretical affinities between anti-racist feminism, post/anti colonial thought, and settler colonialism, can better buttress community art action practices.

Anti-racist feminist educational approaches are never fixed, and should be viewed as a process and a journey. Developing, participating, and reflecting on the Recognizing Privilege \& Oppression Workshop with articule proved to be a deep learning experience for myself, and I believe also for articule and the other workshop participants. The changes after the workshop and strategic planning sessions were so vast within articule, there were times when the community I had become familiar and comfortable with felt very different. Admittedly, some moments brought surprise and challenge when confronted by dissenting views, but witnessing these new voices entering the changing organization provided opportunities to reflect on how theory and action work together to provoke change. To keep artistic visioning fresh, flexible and fluid is to welcome creative risk taking and to support the imagination. It is undeniable that institutions and the people who inhabit them need to be challenged on

44 MAULE-O'BRIEN, Skye. Exploring community outreach initiatives for artist-run centers: A case study using anti-racist feminist pedagogies to create inclusive spaces for knowledge exchange. M.A thesis (Educational Studies), Concordia University, 2011, p. 51. norms and belief systems around excellence in the arts, and space must be allowed for difference. But space also must be made for conversations to confront such elitism by offering counter-views, while simultaneously providing support for people to work through difficult or painful emotions such new knowledge can bring, without recentering dominant ideologies.

I am thankful for articule's continued support and commitment to the visions of their membership; this was the driving force in community leadership that was necessary for the institutional reflection and the resulting changes that occurred. They worked to validate the importance of a reflection process and provided the energy needed to tackle complex institutional and structural challenges. This commitment is not unique to articule. Community-based art projects that are trying to create dialogue and break oppressive traditions are born in every neighbourhood, in cities all around the world. The research findings here speak to many contemporary urban centres. The need for change is relevant to all art institutions in order to further incorporate the diverse voices of their membership, audience, and participants. There is still much to be done in the development of strategies for creative spaces to combat white supremacy and other interlocking forms of oppression. To positively incorporate difference, communities and institutions need to work collaboratively with shared resources and break from divisive competitive traditions that only damage healthy community knowledge exchange. 
Skye Maule-O'Brien, traduit par Micheline Giroux-Aubin et

Alessandra Mariani

Initiatives de sensibilisation communautaire pour des centres d'artistes autogérés. Étude de cas basée sur une pédagogie féministe antiraciste en vue de la création d'espaces intégrés voués au partage des connaissances

Au fur et à mesure que les centres urbains se développent et se diversifient, la nécessité de voir les institutions civiques refléter ces changements dans un monde qui se globalise n'a jamais été aussi flagrante. Les défis changeants auxquels font face les institutions d'art et l'univers artistique traditionnel ne sont pas encore représentés correctement, dont l'inclusion de la diversité des communautés qui peuplent les sociétés urbaines. Ma recherche sur les pédagogies incorporant les arts, la créativité et l'imagination et leurs liens avec l'éducation des adultes privilégie la conscientisation accrue et la création de ponts entre les différentes cultures ${ }^{1}$. Je soutiens que la promotion de formes alternatives de construction de savoirs par le biais de l'enseignement des arts facilite la construction de liens communautaires solides et favorise le changement institutionnel autant que la réflexion critique individuelle.

Dans une ville comme Montréal (Québec) où des barrières invisibles fondées sur la langue, la race et le statut social fragmentent le paysage en zones géographiques visibles, il devient important d'analyser les conditions souvent incontestables des privilèges octroyés aux individus et aux institutions. Issu de la recherche effectuée dans le cadre de ma maîtrise en sciences de l'éducation à l'Université Concordia, cet article est construit sur trois principales composantes qui s'éclairent mutuellement. La première est constituée des fondements de la recherche pédagogique féministe antiraciste axée sur les façons de promouvoir une diversité accrue des institutions d'art. La seconde est une synthèse des résultats de mon étude de cas: une recherche-action d'un atelier de deux jours intitulé Recognizing Privilege and Oppression et mené conjointement avec le conseil d'administration et le personnel d'un centre montréalais géré par des artistes, articule ${ }^{2}$, voué aux pratiques artistiques contemporaines et à l'engagement social. La participation d'articule découlait du besoin que cet organisme avait identifié de réfléchir sur ses propres traditions et politiques, afin de déterminer si elles correspondaient à son mandat et respectaient les réalités changeantes du climat culturel et politique. Ainsi, dans le but de "provoquer le dialogue [...] de générer une pensée critique et de promouvoir une diversité de pratiques et d'expériences dans les champs artistiques et sociaux $"^{3}$, l'atelier expérimentait les possibilités d'ouvrir des espaces artistiques

1 MAULE-O'BRIEN, Skye. « Demystifying the art museum:

Benefits of art education ". The Concordia Undergraduate

Journal of Art History, vol. 2, 2006, pp. 9-20.

2 Bien que ce soit le nom d'un organisme, articule ne s'écrit pas avec la majuscule initiale.

3 ARTICULE. Mandate. <www.articule.org/web/menu02/

mandat_en.html> (consulté en novembre 2012). 
accessibles et inclusifs voués à la création et au partage des connaissances. Les données nécessaires à mon étude ont été colligées à l'aide d'approches ethnographiques et auto-ethnographiques. Dans ce cadre, cet article se penche sur les possibilités de sensibilisation qui font la promotion de solutions et de concepts créatifs. La troisième composante réside dans le fait que l'article offre aux institutions d'art des suggestions concrètes, accessibles et flexibles pour les aider à diversifier leurs publics, leurs membres et leurs participants et les amener à incorporer la différence et le dialogue de façon positive.

L'article cherche par ailleurs à répondre aux questions énumérées ci-dessous qui sont liées aux transformations et aux défis des centres gérés par des artistes dans leurs efforts d'élargir et d'améliorer les initiatives de sensibilisation à la communauté:

- Pour mieux s'intégrer aux communautés présentes dans leur milieu, quels changements les centres d'artistes autogérés doivent-ils mettre en œuvre?

- Les notions d'accès et de privilèges sont-elles traitées en continu?

- Comment les changements peuvent-ils être actualisés en période de contraintes budgétaires?

- Comment les pratiques de conservation, de programmation et de monstration peuvent- elles être questionnées et modifiées le cas échéant?

Finalement, l'article fait état des leçons que peuvent tirer les musées et les grandes institutions civiques des organisations artistiques gérées par la communauté ainsi que des possibilités de collaboration qu'elles génèrent. 